\title{
PERANCANGAN APLIKASI KONSULTASI ONLINE UNTUK GANGGUAN JIWA BERBASIS WEB
}

\author{
Design Application Consultation Online Mental Illness Web Based \\ Eka Sari Octaviani ${ }^{1}$, Yunita Sari ${ }^{1}$, Erwin Suhandono ${ }^{1 *}$ \\ ${ }^{1}$ Universitas Persada Indonesia YAl Jakarta, Jl Salemba Raya no 7-9 Jakarta Pusat 10340, Indonesia
}

Informasi artikel
Diterima: $03 / 02 / 2019$
Direvisi : $12 / 02 / 2019$
Disetujui: 12/02/2019

\begin{abstract}
Abstrak
Sebagian besar orang yang mengunjungi psikiater merasa canggung bahkan malu karena kuatnya stigma negatif dari masyarakat terhadap orang-orang yang berobat ke dokter jiwa. Masyarakat cendrung masih mempercayai gangguan jiwa adalah penyebab kurangnya iman atau masuknya roh halus ke dalam tubuh manusia yang lemah. Tulisan ini menjelaskan tentang perancangan aplikasi untuk memudahkan masyarakat dalam memahami serta mampu mengatasi kesehatan jiwa secara daring yang begitu informatif bersama psikolog maupun psikiater terpercaya. Dengan metode pengumpulan data dan analisa kebutuhan menghasilkan Aplikasi Konsultasi Online untuk Gangguan Jiwa berbasis web. Berdasarkan hasil uji coba yang dilakukan menggunakan metode black box aplikasi ini mempermudah penguna dalam menggunakan aplikasi serta memudahkan mencari informasi tentang kesehatan jiwa.
\end{abstract}

Kata Kunci: aplikasi, konsultasi, gangguan jiwa.

\begin{abstract}
Most of the people who visit psychiatrists feel awkward and even embarrassed because of the strong negative stigma from the community towards people who go to the psychiatrist. People tend to believe still that mental disorders are a cause of lack of faith or the entry of spirits into a weak human body. This paper describes the design of applications to make it easier for people to understand and be able to deal with mental health online that is so informative with psychologists and trusted psychiatrists. With the method of data collection and needs analysis, it produces an online consultation application for web-based mental disorders. Based on the results of trials conducted using the black box method this application makes it easy for users to use the application and makes it easy to find information about mental health.
\end{abstract}

Keywords: application, consultation, mental illness.

*Penulis Korespondensi: +62 8170171002

email: erwin.suhandono@upi-yai.ac.id 


\section{PENDAHULUAN}

Perkembangan ilmu dan teknologi yang semakin pesat mempengaruhi kepribadian seseorang. Kehidupan sehari-hari yang tidak lepas dari teknologi kini menjadi bagian dari gaya hidup seseorang. Terdapat faktor eksternal maupun internal yang dapat menyebabkan seseorang mengalami gangguan kejiwaan. Gangguan jiwa merupakan suatu kondisi dimana keberlangsungan fungsi mental menjadi tidak normal baik kapasitasnya maupun keakuratannya.

Berdasarkan data dari Riskesdas tahun 2007 menunjukan angka nasional gangguan jiwa, gangguan mental emosional (kecemasan, depresi) pada penduduk usia kurang lebih 15 tahun adalah $11,6 \%$ atau sekitar 19 juta penduduk, sedangkan gangguan jiwa berat rata-rata sebesar 0,64\% atau sekitar 1 juta penduduk. Di Indonesia sendiri, remaja di bawah usia 15 tahun yang mengalami depresi pada 2007 mencapai 16 persen atau sekitar 19 juta orang. Memasuki 2010, angka itu dipastikan lebih tinggi lagi. Menurut perhitungan utilisasi layanan kesehatan jiwa ditingkat primer, sekunder dan tersier, kesenjangan pengobatan diperkirakan lebih dari $90 \%$ hanya 10\% yang membutuhkan layanan kesehatan jiwa terlayani di fasilitas kesehatan.

Sebagian besar orang yang mengunjungi psikiater merasa canggung bahkan malu karena kuatnya stigma negatif dari masyarakat terhadap orang-orang yang berobat ke dokter jiwa. Masyarakat cendrung masih mempercayai gangguan jiwa adalah penyebab kurangnya iman atau masuknya roh halus ke dalam tubuh manusia yang lemah. Padahal kelebihan hormon dopamine dan serotonin, faktor genetika, faktor lingkungan, dan faktor lainnya yang dapat menyebabkan seseorang mengidap gangguan jiwa, yang jika tidak diatasi akan menjadi proses yang panjang dan sulit untuk diobati, dan sudah pasti tidak mampu melakukan aktivitas kehidupan sehari-hari atau bertanggung jawab atas dirinya sendiri dengan sadar. Disinilah peranan psikiater sangat membantu untuk permasalahan yang sedang dihadapi. Dalam hal peran fungsi dan tanggung jawab perawat psikiatri dalam meningkatkan kesehatan jiwa adalah dengan meningkatkan percaya diri pasien dan mengajarkan untuk berinteraksi dengan orang lain, sehingga Orang Dengan Gangguan Jiwa (ODGJ) dapat melakukan kegiatan sehari-hari dengan normal meski harus tetap dalam pengawasan psikiater dan keluarga.

Berdasarkan latar belakang tersebut permasalahan yang menjadi fokus utama adalah seperti apa aplikasi yang mempermudah proses konsultasi pasien atau pendamping dengan dokter jiwa.

Tujuan yang ingin dicapai dari penelitian ini adalah merancang suatu sistem aplikasi berbasis web yang diharapkan dapat memudahkan pasien dalam melakukan konsultasi dengan dokter jiwa, serta ,enjadi wadah untuk menyediakan informasi seputar kesehatan jiwa.

\section{METODOLOGI PENELITIAN}

Metode pengumpulan data dilakukan untuk mendapatkan suatu informasi yang dibutuhkan dalam mencapai tujuan penelitian. Pengumpulan data dalam penelitian ini menggunakan metode-metode sebagai berikut:

1) Metode Observasi (Pengamatan)

Menurut Rapina (Rapina, dkk., 2013), observasi merupakan suatu teknik yang digunakan untuk mengumpulkan data dengan cara melakukan pengamatan secara langsung ke tempat yang dijadikan objek penelitian. Metode pengamatan atau metode observasi pada sistem ini dilakukan dengan cara mengumpulkan data, informasi, dan mempelajari catatan serta dokumen yang ada.

2) Metode Wawancara (Interview Research)

Menurut Rapina (Rapina, dkk., 2013), Wawancara merupakan salah satu teknik untuk mengumpulkan data dengan cara menanyakan secara langsung kepada pihak yang berkaitan dengan penelitian. Wawancara yang dilakukan adalah memberikan kuisioner ke 10 responden.

\section{3) Studi Pustaka}

Menurut Rapina (Rapina, dkk., 2013), studi pustaka adalah mencari atau mengumpulkan bahan yang berhubungan dengan masalah yang diteliti untuk memperoleh data sekunder dengan membaca, mempelajari, dan mendalami literatur-literatur yang berhubungan dengan masalah yang diteliti. 


\section{HASIL DAN PEMBAHASAN}

Analisis Sistem

Analisis sistem dapat didefinisikan sebagai penguraian dari suatu sistem informasi yang utuh kedalam bagian-bagian komponennya dengan maksud untuk mengidentifikasikan dan mengevaluasi permasalahan, kesempatan, hambatan yang terjadi dan kebutuhan yang diharapkan sehingga dapat sesuai dengan yang diharapkan. Mengidentifikasi masalah merupakan langkah pertama yang dilakukan dalam tahap analisis sistem. Masalah dapat diidentifikasikan sebagai suatu pertanyaan yang diinginkan untuk dipecahkan.

Berdasarkan hasil wawancara dengan berbagai pihak terlibat didapati kesimpulan permasalahan yaitu sulitnya mencari dokter jiwa serta untuk melakukan konsultasi. Permasalahan ini yang akan dijadikan sebagai usulan perancangan dalam sebuah sistem.

\section{Perancangan Sistem}

Perancangan ini meliputi Use Case diagram, Activity diagram, Sequence diagram, Class diagram, perancangan struktur tabel dan rancangan antarmuka.

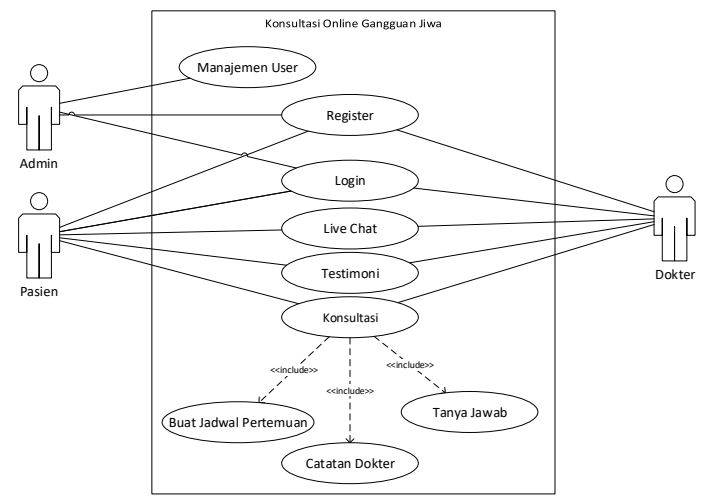

Gambar 1 Use case diagram

Dalam gambar 1 dijelaskan bagaimana alur suatu proses seorang pasien berinteraksi dengan seorang dokter melalui website.

Gambar 2 menjelaskan bagaimana admin melakukan aktifitas saat melihat data dokter yang terdapat dalam sebuah sistem.

Di aktifitas ini (lihat gambar 3) seorang pasien melakukan pendaftaran melalui online sehingga pasien dapat divalidasi oleh sistem kapan pasien berkonsultasi dengan dokternya melalui website. Sedangkan pada gambar 4, aktifitas diagram login si pasien melakukan login disistem dengan masuk ke halaman website rumah sakit dengan menginput nama username dan password.

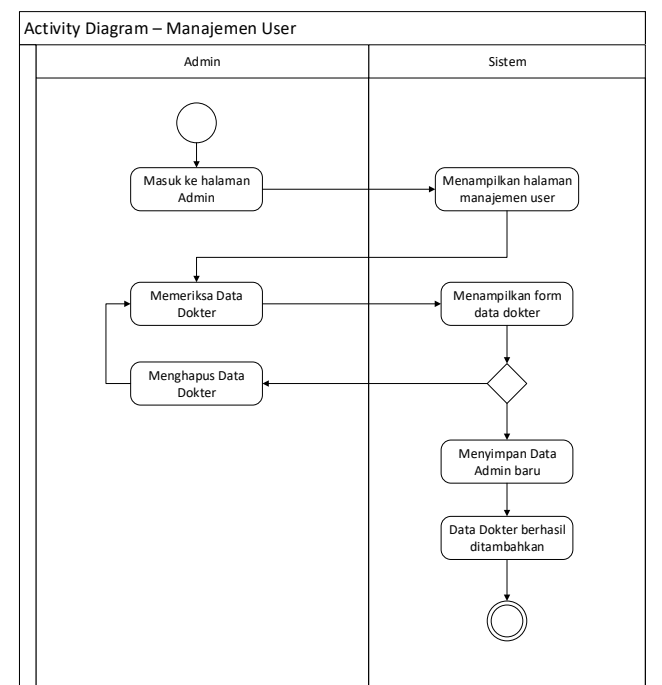

Gambar 2 Activity diagram manajemen user

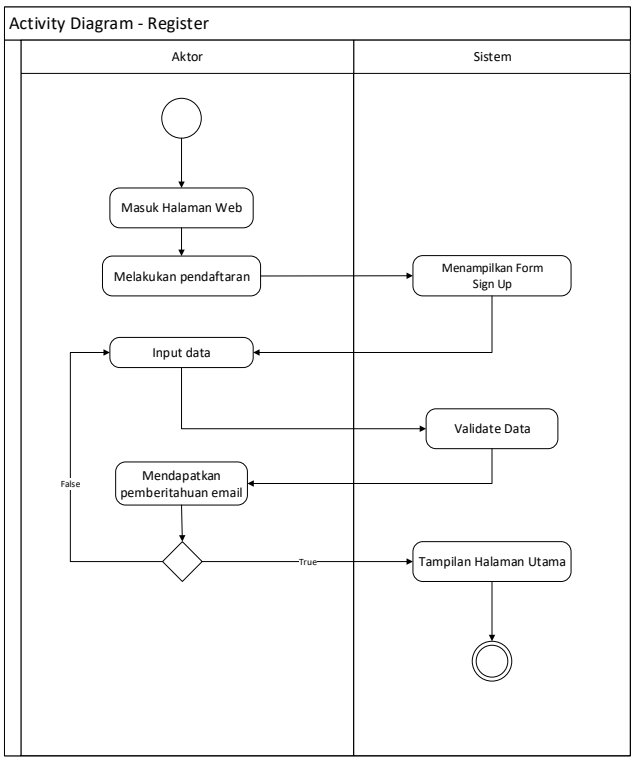

Gambar 3 Activity diagram register

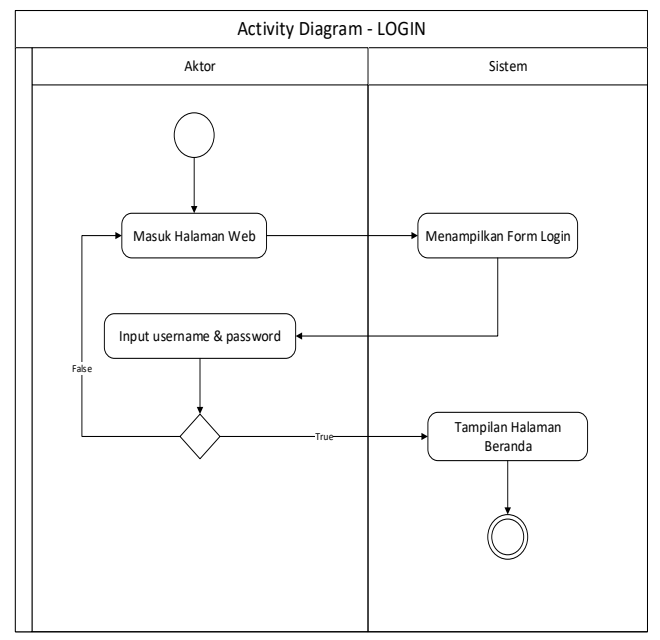

Gambar 4 Activity diagram login 


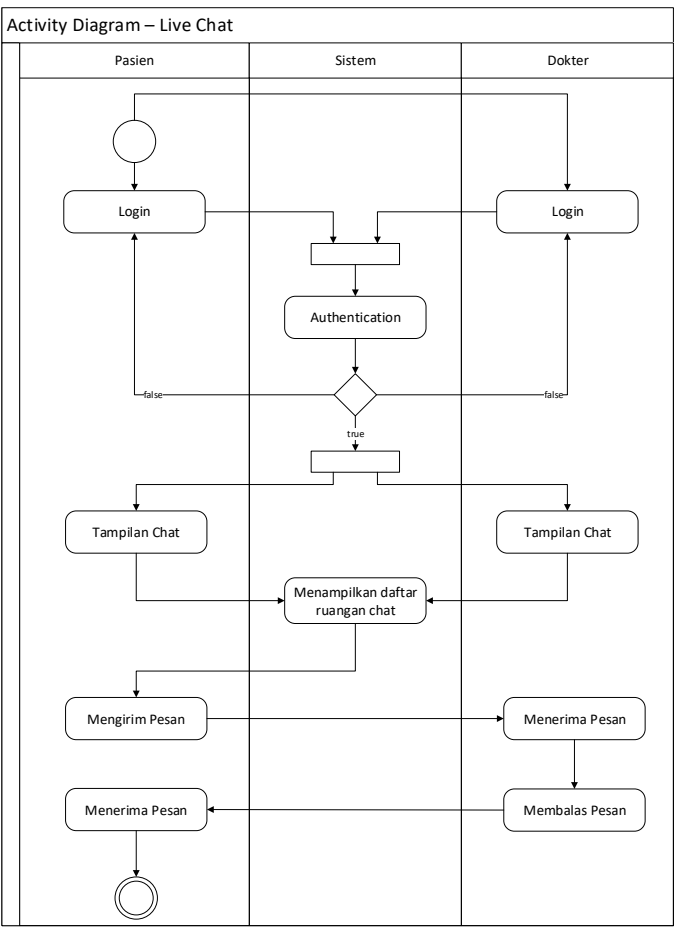

Gambar 5 Activity diagram live chat

Pada gambar 5 dijelaskan bahwa sipasien melakukan konsultasi online dengan dokter melalui website rumah sakit dengan menampilkan ruang chat pada sistem rumah sakit tersebut.

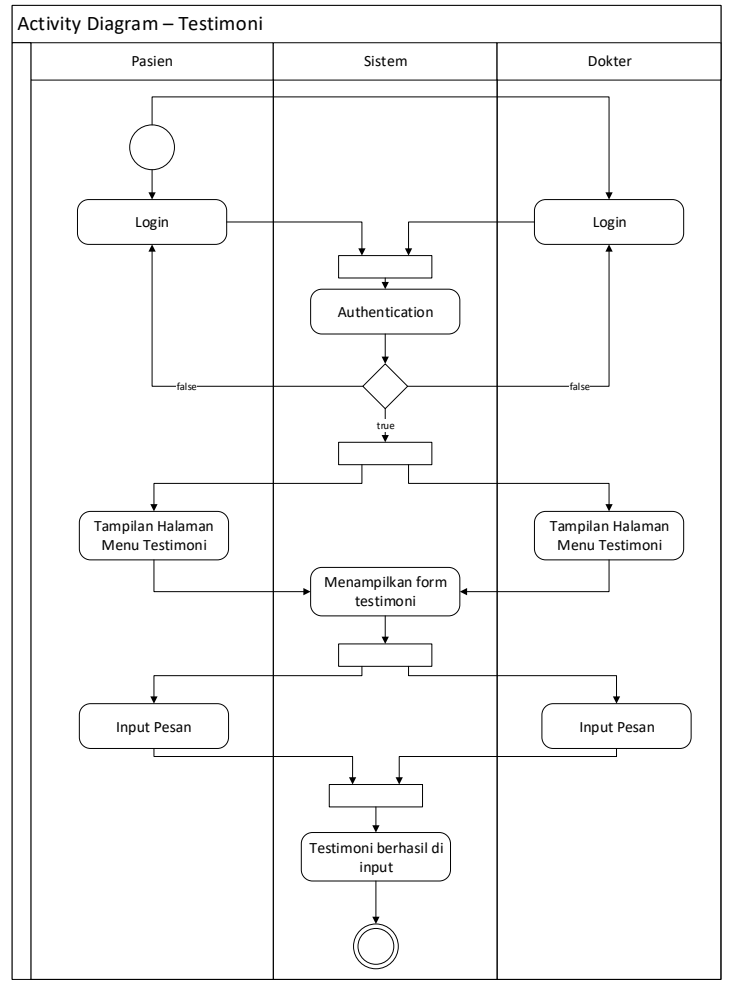

Gambar 6 Activity diagram testimoni
Pada aktifitas diagram gambar 6 yang dibuat perancangan pada uml adalah bahwa pasien melakukan verifikasi antara dosen dangan pasien, dimana pasien melakukan sebuah testimoni kepada dokternya melalui online.

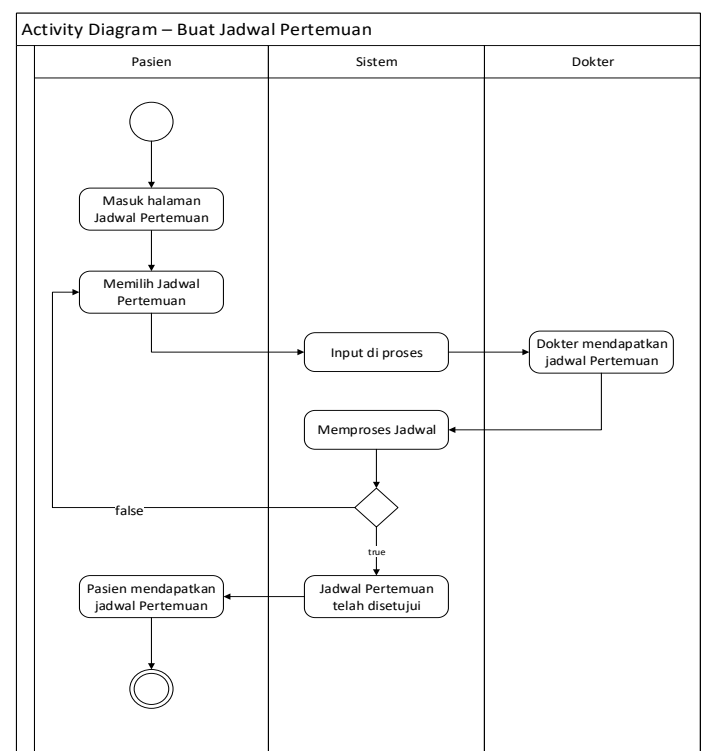

Gambar 7 Activity diagram jadwal pertemuan

Pada aktifitas diagram gambar 7 tersebut, dimana pasien melakukan pemilihan jadwal pertemuan dengan dokter yang kemudian oleh dokter melihat jadwal pertemuan tersebut, untuk disetujui oleh dokter untuk melakukan pertemuan tersebut.

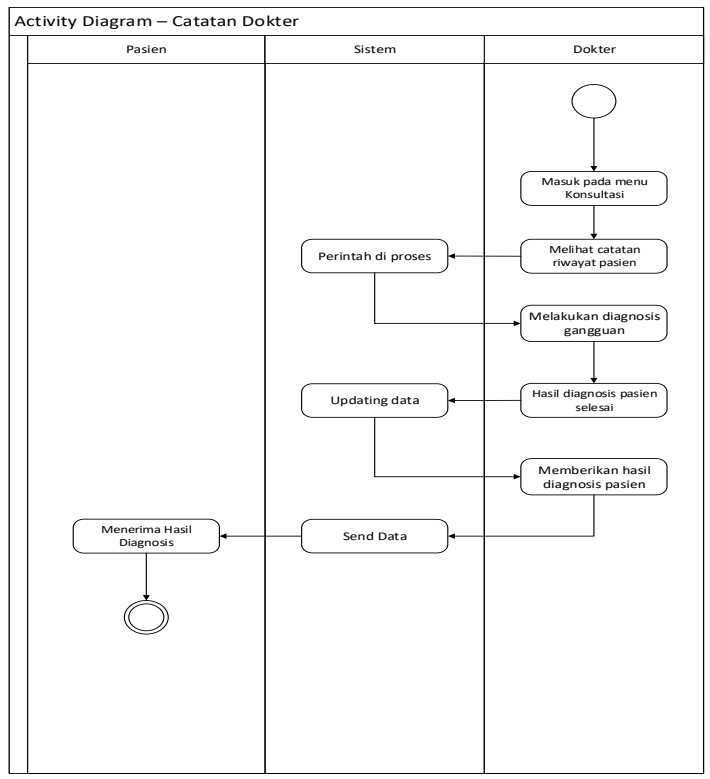

Gambar 8 Activity diagram catatan dokter 
Pada aktifitas diagram ini dokter prosedur yang ditampilkan melihat riwayat penyakit pasien dan melakukan diagnosa terhadap pasien secara online dan memberikan hasil diagnosa tersebut kepada pasien (lihat gambar 8).

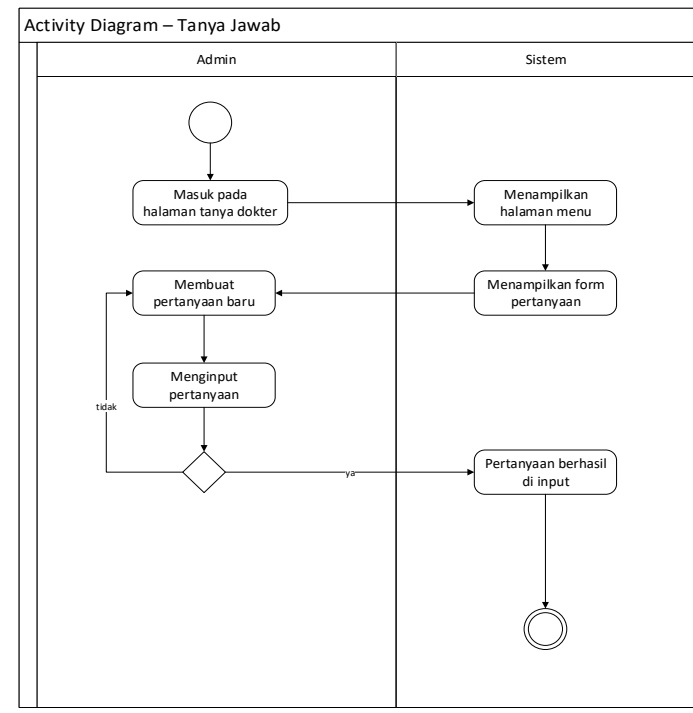

Gambar 9 Activity diagram tanya jawab

Di aktifitas diagram ini adalah admin menginput semua pertanyaan yang dilakukan pasien untuk ditampilkan dalam sistem yang telah dibuat secara online.

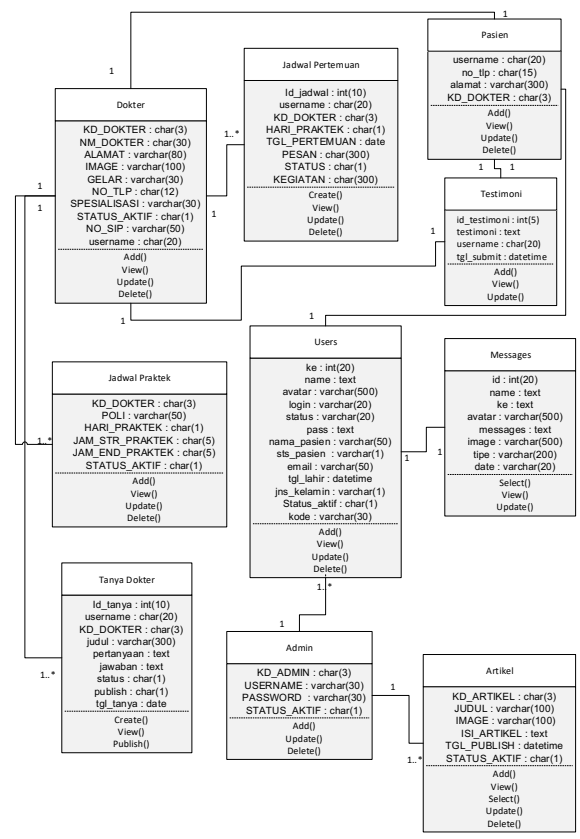

Gambar 10 Class diagram aplikasi konsultasi online untuk gangguan jiwa

Dalam class diagram pada gambar 10 menjelaskan data base yang terdapat pada program yang akan ditampilkan.

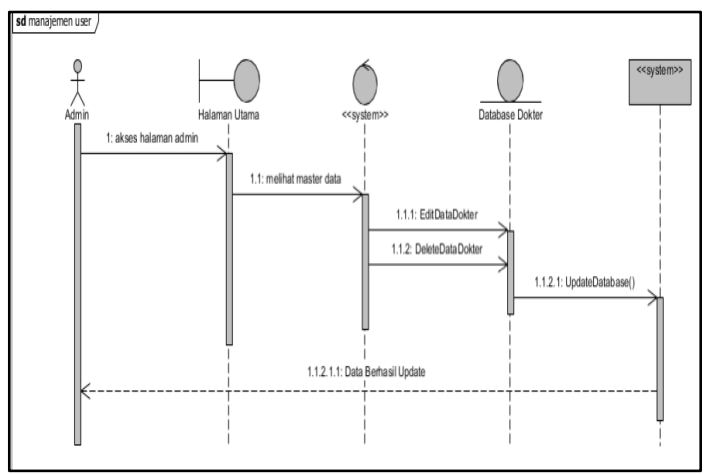

Gambar 11 Sequence diagram - manajemen user

Sequence diagram pada gambar 11 ini, menjelaskan bagaimana website aktifitas dokter dalam sebuah sistem.

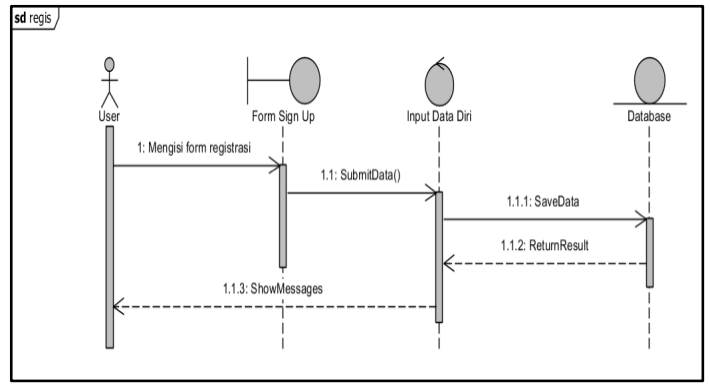

Gambar 12 Sequence diagram - register

Seorang pasien melakukan pendaftaran melalui online sehingga pasien dapat divalidasi oleh sistem kapan pasien berkonsultasi dengan dokternya melalui website (lhat gambar 12).

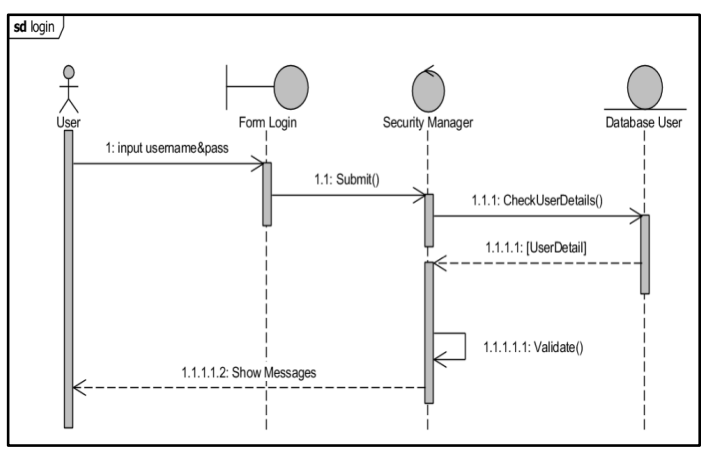

Gambar 13 Sequence diagram - login

Pasien melakukan login pada sistem dengan masuk ke halaman website rumah sakit dengan menginput nama username dan password (lihat gambar 13). Sequence ini menjelaskan bahwa pasien melakukan konsultasi online dengan dokter melalui website rumah sakit dengan menampilkan 
chat pada sistem rumah sakit tersebut (lihat gambar 14).

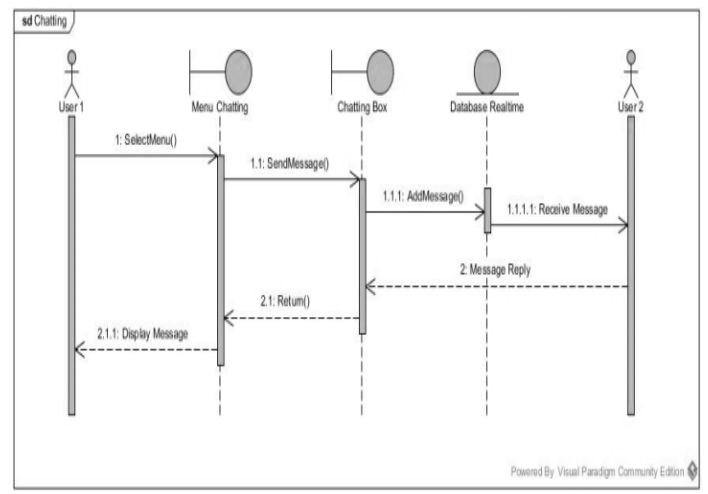

Gambar 14 Sequence diagram - live chat

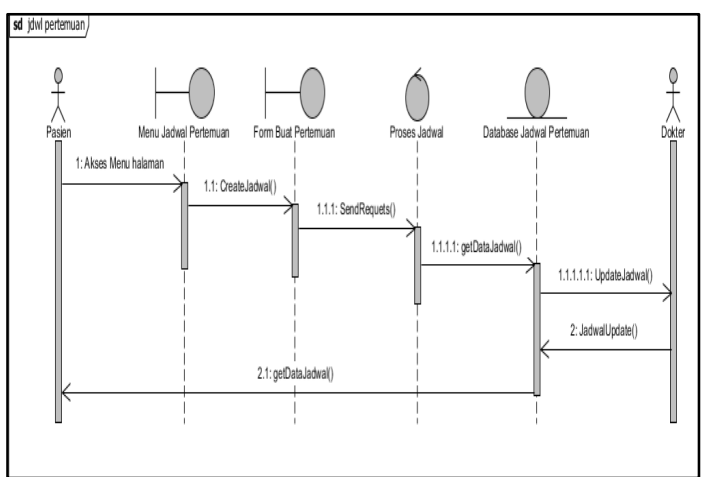

Gambar 15 Sequence diagram - testimoni

Pada aktifitas sequence gambar 15, yang dibuat perancangan pada uml adalah bahwa pasien melakukan verifikasi antara dosen dangan pasien, dimana pasien melakukan sebuah testimoni kepada dokternya melalui online.

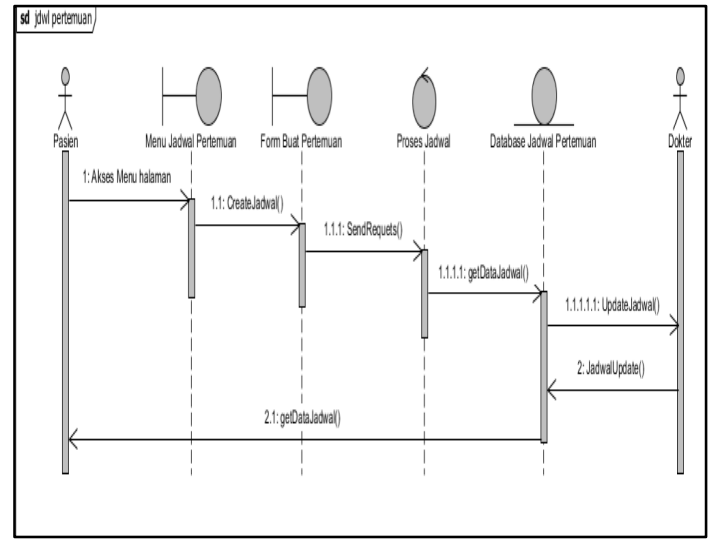

Gambar 16 Sequence diagram - buat jadwal pertemuan

Pasien melakukan pemilihan jadwal pertemuan dengan dokter yang kemudian oleh dokter melihat jadwal pertemuan tersebut, untuk disetujui oleh dokter untuk melakukan pertemuan seperti pada gambar 16.

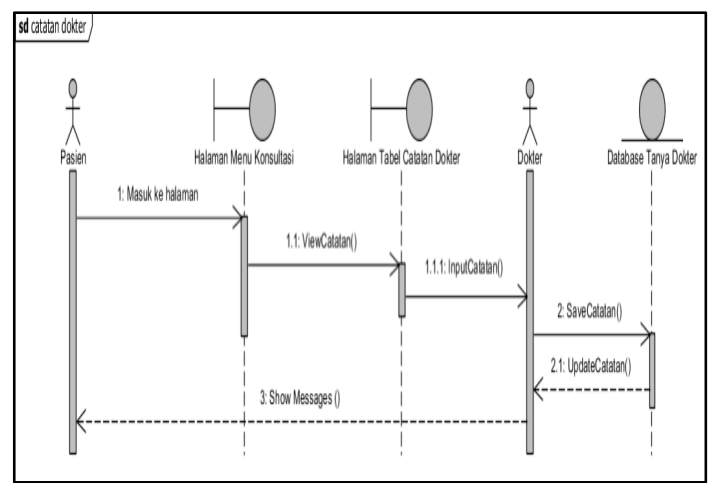

Gambar 17 Sequence diagram - catatan dokter

Pada gambar 17, sequence alur prosedur yang ditampilkan dokter melihat riwayat penyakit pasien dan melakukan diagnosa terhadap pasien secara online dan memberikan hasil diagnosa tersebut kepada pasien.

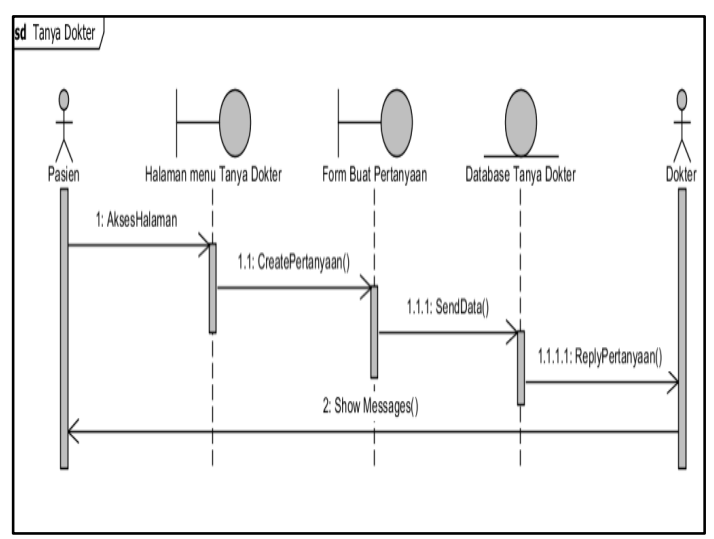

Gambar 18 Sequence diagram - tanya jawab

Sesuai gambar 18, admin menginput semua pertanyaan yang dilakukan pasien untuk ditampilkan dalam sistem yang telah dibuat secara online.

\section{Implementasi}

Tahapan ini merupakan tahapan aplikasi akan dibuat setelah melakukan analisa dan perancangan pada bab sebelum nya. Aplikasi Konsultasi Online untuk Gangguan Jiwa berbasis web ini dibuat dengan bahasa pemorgraman PHP, HTML, serta dengan framework Bootstrap agar web menjadi responsif. 
Implementasi bertujuan untuk mengkonfirmasi modul-modul perancangan, sehinga pengguna dapat memberikan masukan kepada pembangun sistem. Tampilan Antarmuka Aplikasi Konsultasi Online untuk Gangguan Jiwa berbasis web.

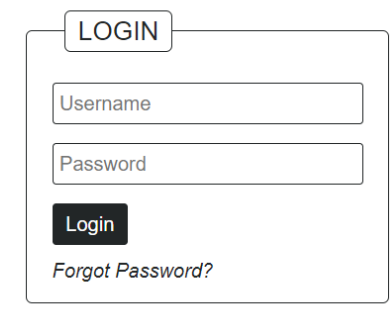

Gambar 19 Dialog login

Dialog pada gambar 19, merupakan dialog login user (pasien dan dokter) wajib memasukan user dan password.

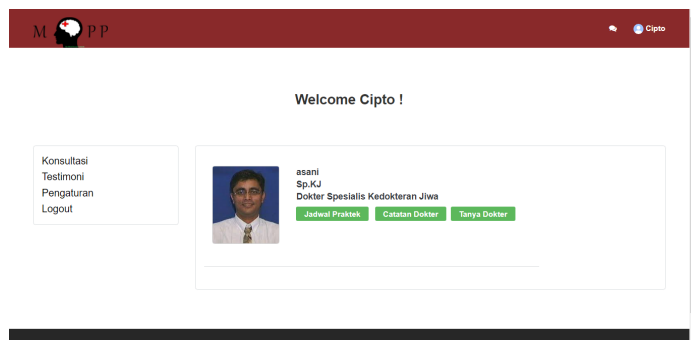

Gambar 20 Menu utama aplikasi konsultasi online untuk gangguan jiwa berbasis web

Menu utama ini merupakan tampilan utama dimana menu dan menu item dibagi berdasarkan hak aksesnya masing-masing. Di menu utama ini user dapat memilih konsultasi yang diinginkan (lihat gambar 20).

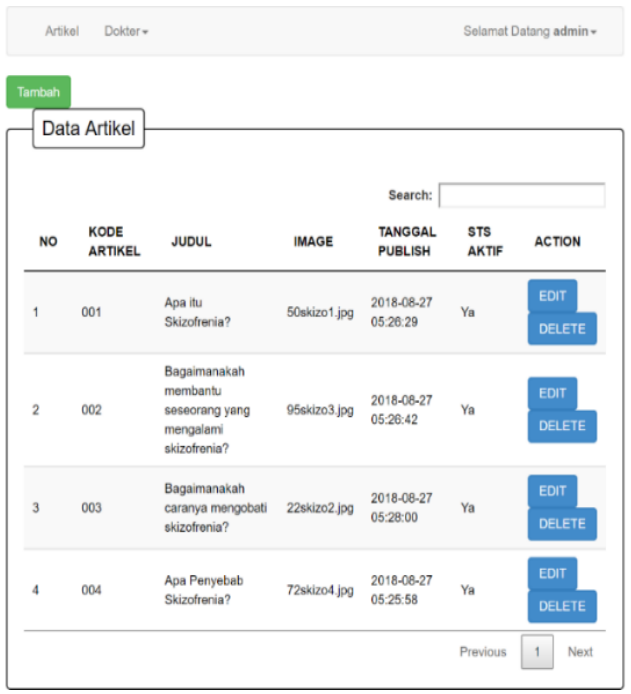

Gambar 21 Menu data artikel
Menu pada gambar 21, merupakan mengelola penerbitan, editing, maupun hapus artikel. Artikel disini memuat informasi seputar kesehatan jiwa.

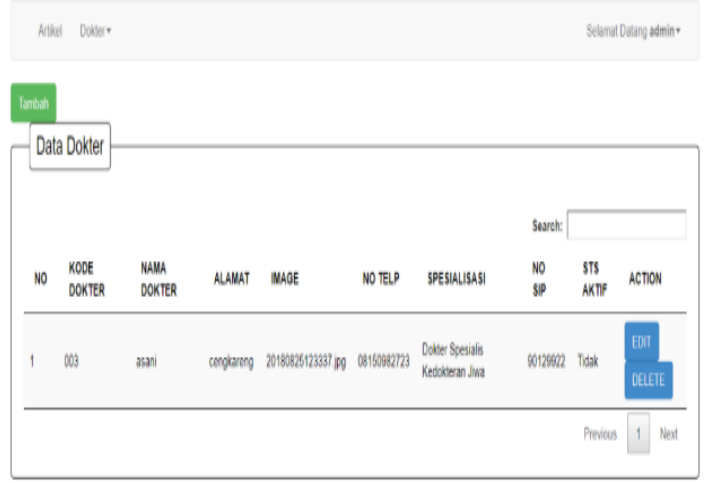

Gambar 22 Menu data dokter

Menu ini mengelola data dokter yang telah mendaftar ke sistem. Admin akan menghapus keanggotaan jika dokter memasukan data palsu (lihat gambar 22).

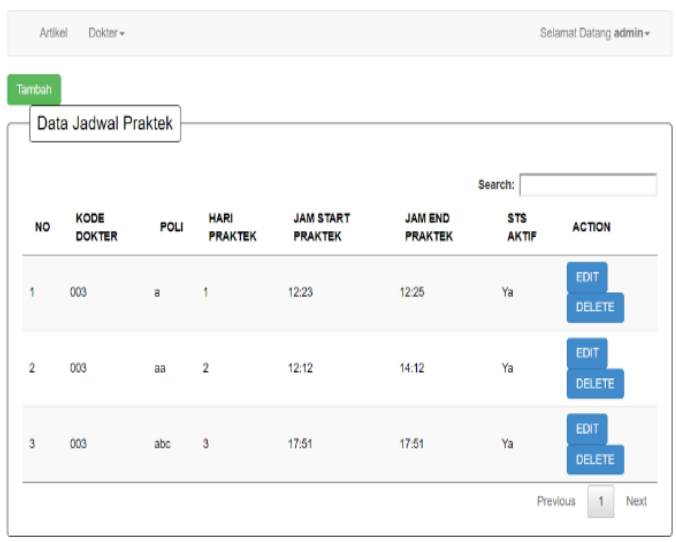

Gambar 23 Menu data jadwal praktek

Gambar 23, merupakan tampilan menu untuk mengetahui Data Praktek yang dokter miliki serta menambahkan data jadwal dokter baru ke dalam sistem. Menu pada gambar 24 digunakan untuk membuat jadwal pertemuan, pasien dapat langsung memilih tanggal yang bisa dipilih ketika meng-klik tombol "Buat Jadwal Pertemuan".

Menu pada gambar 25, merupakan menu konsultasi pertemuan dokter akan mencatat diagnosa pasien ke dalam sistem. Catatan dokter juga dapat dilihat pasien pada halaman menu konsultasi. Menu pada gambar 26, merupakan menu pasien mengajukan pertanyaan ke dokter yang bersangkutan dan dapat mempublish pertanyaan ke halaman tanya dokter. 


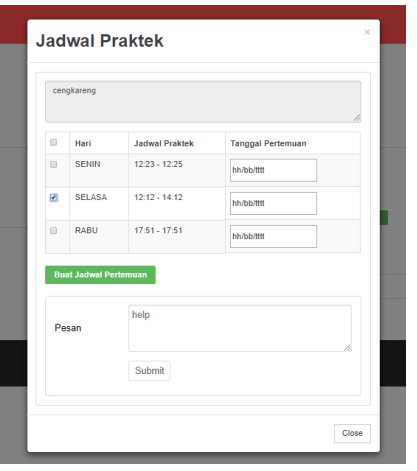

Gambar 24 Menu input buat jadwal pertemuan

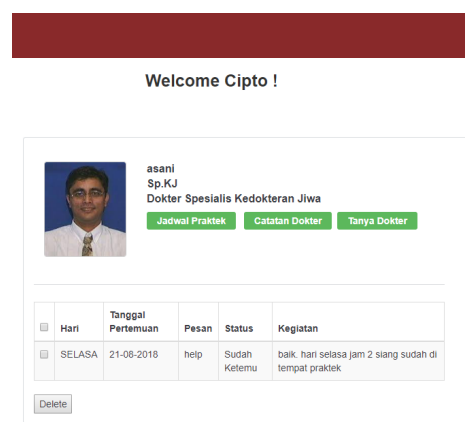

Gambar 25 Menu catatan dokter

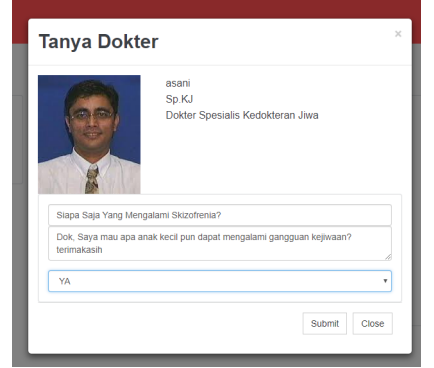

Gambar 26 Menu tanya dokter

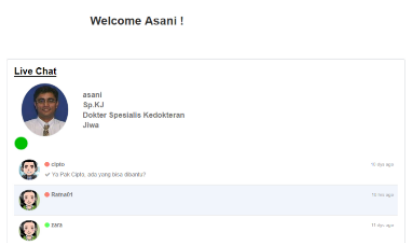

Gambar 27 Menu live chat

Pada halaman ini pasien dapat melakukan live chat dengan dokter yang sedang online setelah melakukan login (lihat gambar 27). Pada gambar 28 , menampilkan halaman testimoni pengguna yang dapat memberikan pengalaman mereka dalam menggunakan aplikasi ini.

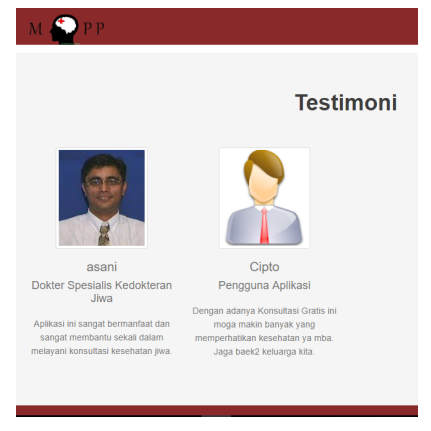

Gambar 28 Menu testimoni

\section{SIMPULAN}

Aplikasi ini berguna dalam membantu pasien untuk menemukan dokter yang dibutuhkan serta memudahkan pasien dalam berkomunikasi untuk melakukan konsultasi secara online dengan tampilan Aplikasi yang sederhana dan mudah dipahami penguna. Aplikasi ini juga sangat informatif dalam memberikan pengetahuan lebih tentang kesehatan jiwa. Tampilan Aplikasi ini dapat dibuka melalui semua jenis perangkat sehingga memudahkan pengguna dalam melakukan konsultasi secara online.

\section{DAFTAR PUSTAKA}

American Psychiatric Association (2013). Diagnostic and statistical manual of mental disorders Fifth Edition. Arlington: VA American Psychiatric Publishing.

A.S Rosa dan M. Shalahudin (2016). Rekayasa Perangkat Lunak (Terstruktur dan Berorientasi Objek). Bandung: Penerbit Informatika Bandung.

Maslim, Rudi. 2013. Buku saku Diagnosis Gangguan Jiwa. Jakarta: PT Nuh Jaya.

Naista David. 2016. Bikin Framework PHP sendiri dengan OOP dan MVC, Jogyakarta: Lokomedia.

Rapina, Jerry dan Yenni Carolina. 2011. Pengaruh Penerapan Sistem Administrasi Perpajakan Modern Terhadap Kepatuhan Wajib Pajak (Survey Terhadap Kantor Pelayanan Pajak Pratama Bandung Cibeunying). Jurnal Riset Akuntansi Vol.III No.2 Oktober 2011

Sugiarti, Yuni, S.T.M.Kom, 2013. Analisis dan Perancangan UML. Yogyakarta: Graha Ilmu.

Taufiq, Rohmat. 2013. Sistem Informasi Manajemen. Yogyakarta: Graha IImu.

Yakub dan Vico Hisbanarto. 2014. Sistem Informasi Manajemen Pendidikan. Yogyakarta: Graha Ilmu. 